\author{
日生病院消化器内科 \\ 吉田 著 ${ }^{\circ}$ 戸田 欣治
}

\title{
A CASE OF MACROAMYLASEMIA
}

\author{
Akira Yoshida, MD and Yoshiharu Toda, MD \\ Division of Gastroenterology, Department of Internal Medicine, Nissei Hospital, Osaka
}

\begin{abstract}
概要 53 才の男. 口中苦味, 喀疢, 耳鳴（何れも軽度）を主訴として昭和47年10月来院, 腎機能に著 変を認めず，尿amylaseは常に低値を示すにもかかからず，血清amylaseが常に高值を持続し，amylase （以下Amと略す）clearanceの著明な低值によりmacroamylasemiaを疑い，検索の結果，血清中に蛋白 と結合したAmの存在が認められた。本症例の血清Amは電気泳動で原点より陽極寄りに主成分の泳動 帯を認め，通常のAmと異なる電気泳動的性質をるつことが判明した。 カラムゲルクロマトグラフィー の結果, 二つの画認め, 高分子のの分子量約20万前後と推定された，危疫学的検討の 結果, IgAとの結合が認められた。
\end{abstract}

\section{1.はじめに}

1964年, Wilding1)らが血清amylase (Amと略) が持続的に高值を示し，睟，腎疾患を認めず，し かもAm clearanceの異常低值を示す症例を報告し て以来, Berk ${ }^{23}$, Levitt $^{33}$ ら, 同梯の症例が報告(4) されつつあるわが国においてす漸次，報告(6) 11) をみるが，な和希な疾患である。

最近，われわれる萃，腎機能に著変なく，尿 Amは常に低值を示すにも拘らず，血清Amが常に 高値を持続する1例を経験した。ゲル濾過法によ りこの血清Amは高分子量をもち，電気泳動法に より通常のAmと異なる 電気泳動的性質（泳動像 の特異的性質については，すでに報告）されてい ることが明らかとなつたので，ここに報告する。

\section{I. 症例}

患者：53才の男子. 会社経営.

主訴：口中苦味, 喀痰, 耳鳴.

既往歴：特記すべきるのなし。

家族歴：父は事故死. 母は健在. 同胞 3 人健

[昭和51年 2 月 12 日受稿]

本論文の要旨は第81回内科学会近畿地方会 (昭和 48年9月29日)に打いて発表した。
在. 妻は十数年来, 歩行障害あり.子供なし.

現歴病：約 1 年来, 喀痰多く, 軽度の口中苦 味および耳鳴を覚え，排便回数の多い事を訴え当 科を受診した，外来で高Am血症を指摘され，精 查のため，昭和 48 年 2 月 21 日入院した。

入院時現症：体格中等, 栄養良好, 脈拍整, 皮膚の黄疸および貧血を認めず。血圧 $120 / 74$. 胸部理学的所見は異常なく, 腹部は平坦で肝, 脾 を触れず，圧痛，抵抗なし，四肢の腱反射は正常 で病的反射を認めず。

入院時検查所見： 本症例の検査所見はTable 1 に示した。胸部，胃十二指晹部，胆鸾部の $\mathrm{X}$ 線所見には著变なく，逆行性膵胆管造影は不成功 に䅂つたが内視鏡的に乳頭部に著変を認めなかつ た。耳鼻科的にも異常を認めず．翼便異常なく消 化良好で尿蛋白，尿糖を認めず，生化学的娭查所 見でも殆ど異常を認めなかつたが，尿Amにも (正常値 500単位以下) の低值 (平均 141 単位) にもかかわらず, 血清Am (正常值 $32 \sim 160$ 単位) の高値（500〜600単位）が認められた。昭和 47 年 10月来院時より昭和 48 年 2 月まで十数回に亘る Am值の変動の成績はFig. 1 のようで，常に血清 


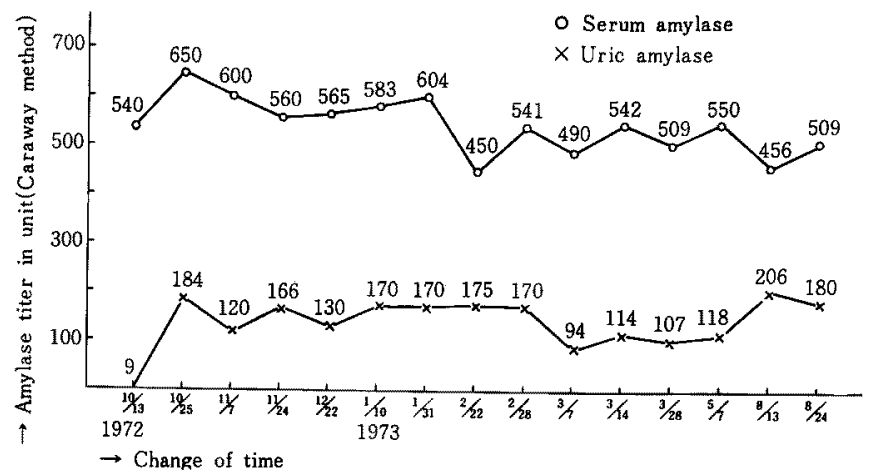

Fig. 1. Change of serum and uric amylase.

Table 1. Examinations on admission.

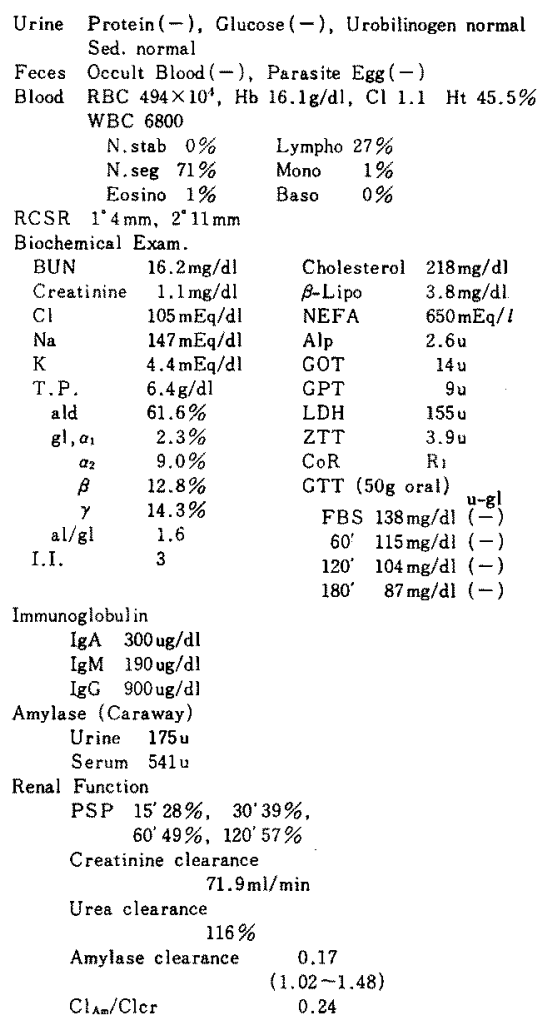

Amの高值を認めた。Am clearanceは0.17にて異 常低值を示し，macroamylasemiaを疑い，以下の 検索を行なつた。

\section{Amylase $の$ 検討}

1）カラムクロマトグラフィーによるAm分
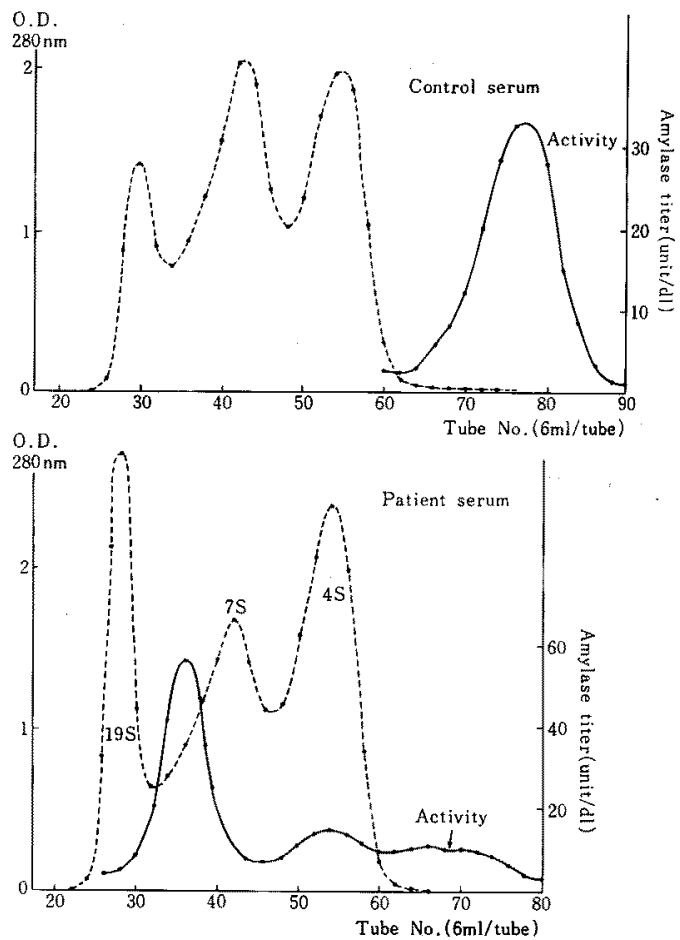

Fig. 2. Gel chromatography by Sephadex G-200.

画 : Sephadex G-200（ $0.1 \mathrm{M}$-tris-HCl緩衝液, $\mathrm{pH} 8.0$ column $2.6 \times 100 \mathrm{~cm})$ にるる゙ルクロマト グラフィーの成績はFig. 2 のよで，患者血清で は19S と $7 \mathrm{~S}$ の間に大部分のAm活性が認められ たが，これに反し対照血清の活性部分は殆よ゙4 S より後に溶出を認めた。 

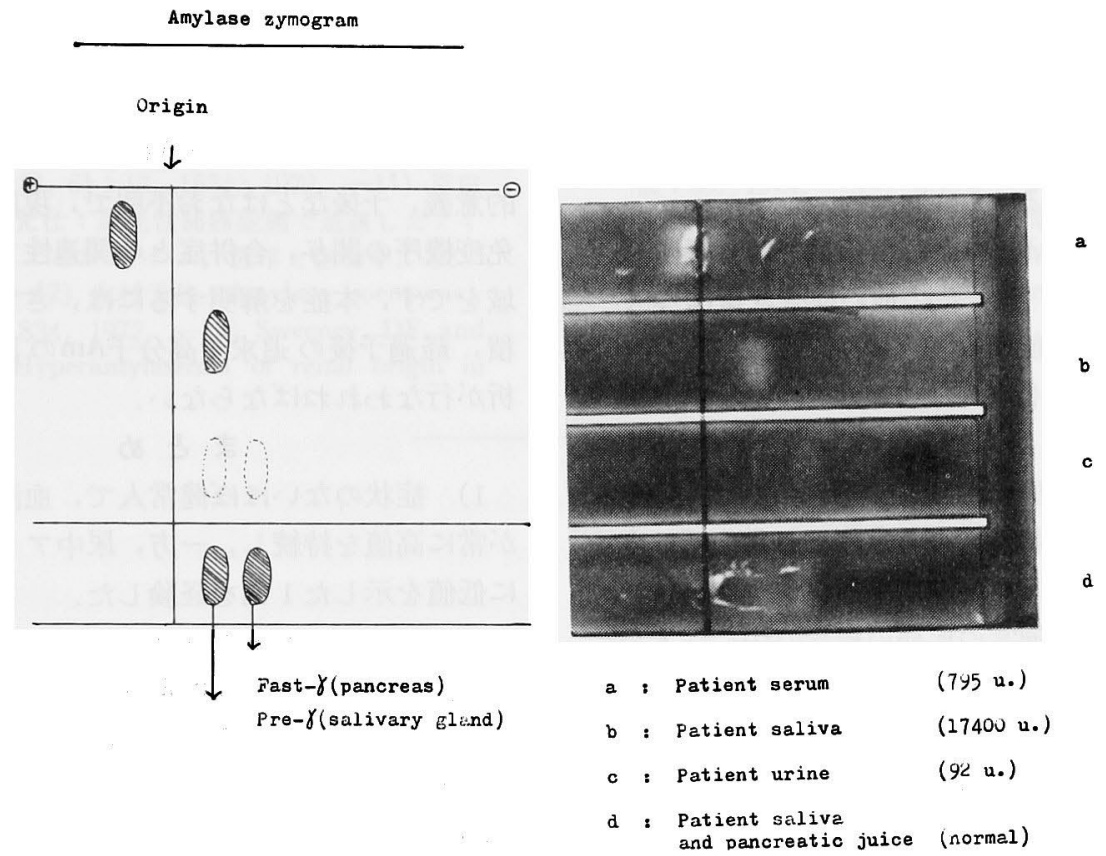

Fig. 3. Amylase isoenzymogram by agar electrophoresis.

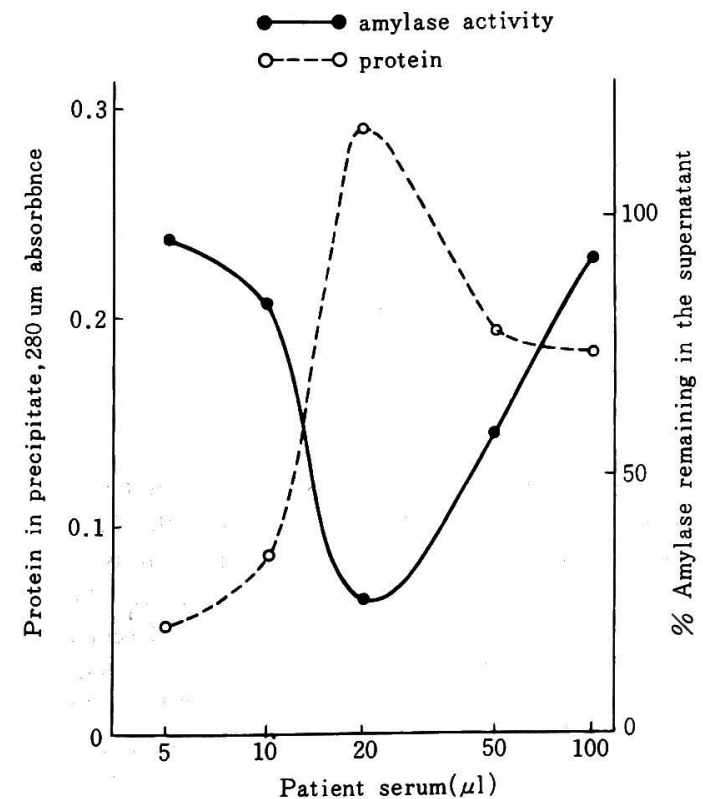

Fig. 4. Precipitation by anti-IgA serum.
2）寒天電気泳動によるAm isoenzyme分画 ${ }^{11}$ 12）：Fig. 3 に示すように本症例の唾液 (pre- $\gamma$ ), 尿（pre- $\gamma$ とfast- $\gamma$ ) は通常の移動度を示したが， 血清は原点より陽極寄りに位置した。

3）免疫学的検討：抗血清（抗人免疫グロブ リン羊血清, Hyland製) に対する反応を検索し た。

抗血清（抗IgA，抗IgG，抗IgM） $0.1 \mathrm{ml}$ に患者 血清を加え，室温にて24時間放置後，3,000 rpm遠 沈分離し，上清のAm活性を測定した。沈殿は生 理食塩水で 3 回洗净後, $2.4 \mathrm{ml}$ の $0.05 \mathrm{M}$ glycine $\mathrm{HCl}$ 緩衝液（pH 3.47）に溶解し， $280 \mathrm{~nm}$ の吸光 度より蛋白濃度を測定した。その結果, 抗IgM, 抗IgGでは反応を認めなかつたのに反し，抗IgA とはFig. 4 のよう上清Amの活性の低下に伴い， 沈降蛋白量の増加が認められた。

\section{考案}

Macroamylasemiaの臨床病態は，腎に病変なく Amの巨大分子化に基づく腎よりの排泄障害に由 
来する高Am血症であり，その成因については Berk $^{2)}$ ，Kizuらは，1）Amの重合，2）免疫グ ロブリンとの結合，3）非蛋白分子化合物との結 合，のいずれかであろう，としているが，なお定 説はないようである。

本症例は外来で高Am血症が指摘され，その後 の頻回の検索です不变で, 他の検査成績は全く 正常を示し，腎機能にも全く異常と認めず，Am clearanceの著明な低值により macroamylasemia疑 い，精検の結果，巨大分子量のAmを含有する事 が判明した．既往症にも特記すべきるのなく，主 訴も軽微で, 全身状態も全く良好で日常生活に支 障なく, 事業の傍らゴルフに堪能（シングルプレ ーャー）であり，通常の疾病の概念の中には入ら ないと思われる。しかしながら従来の報告例では 何らかの疾病をもつものが少なくない。

1967年, Berk ${ }^{2)}$ が初めてmacroamylasemiaとし て報告した 3 例中 2 例はそれぞれ肝硬変，アルコ 一ル中琵であつた，それより前1963年にSweeny ${ }^{13)}$ らは肝炎をもち類似の高Am血症, Am clearance の低下の症例を報告しており，1964年にはWilding1)らが，ッェリアキーの症例で, Sephadex G100 による゙ル汇過で巨大分子量の高Am血症を報 告している。1968年に発表された Levitt ${ }^{83}$ の症 例を吸収不全症候群を伴つており，LevittはAm immunoglobulin complexの形成による吸収不全 と示唆している. macroamylaseに打いてimmunoglobulinとAmとの関連性については，Levittの

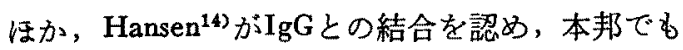
$\mathrm{IgA}^{15) 16)}$ のみならず, $\operatorname{IgG}^{16)}$ との結合例る報告され ている。われわれの症例ではIgAの増量るなく， 吸収不全症候群子認めなかつたが，免疫沈降反応 では，IgAの沈降とともに上清からAm活性が消 失し，IgAとAmとの結合が推定された。IgAの増 量を示唆する原疾患との関連性の追究は, macroamylasemiaの 本態解明に 重要な。手がかりを与え るものと考光られる。

一方, また，本症の生化学的特徽として ${ }^{9310) 17), ~}$ 血清中には沈降定数 $7 \mathrm{~S} \sim 11 \mathrm{~S}$ の高分子量Amが
存在するにもかかからず, 唾液, 尿, 膵液中には 通常のAmだけが存在することで，われわれの症 例でも同様の成績を認めた。

Macroamylasemiaの本態, 疾病論的成因, 臨床 的意義，予後などはな拉不明で，現段階では自己 免疫機序の関与, 合併症との関連性もまだ憶測の 域をでず，本症を解明するには，さらに症例の集 積, 経過予後の追求や高分子Amの詳細な性状解 析が行なわれねばならない。

\section{まとめ}

1）掟状のないほぼ健常人で, 血清アミラーゼ が常に高值を持続し，一力，尿中アミラーゼが常 に低值を示した 1 例を経験した。

2）ゲルクロマトグラフィーによって，本症例 の血清中には高分子（推定分子量約20万）のアミ ラーゼが存在し，本症例はmacroamylasemiaであ ることが確認された。

3）寒天電気泳動により，この血清フミラーゼ は原点上り陽極寄りに泳動帯を認め, 正常のフミ ラーゼと異なる電気泳動的性質を認めた。

3）免疫学的検討の結果, 本症例の高分子ア ラーゼは通常のフミラーゼとIgAとの結合により 生成されたるのであると考えられる。

（実験に御協力をいただたた虎の門病院，臨床化学科 北村元任，原田紀久子両氏に深謝いたしむす。）

\section{文献}

1) Wilding, P, et al Globulin-bound amylase: A cause of persistently elevated levels in serum. Ann Intern Med, 60: 1053, 1964. - 2) Berk, JE et al: Macroamylasemia: A newly recognized cause for elevated serum amylase activity. New Eng J Med, 277: 941, 1967. -3) Levitt, MD and Cooperband, SR: Hyperamylasemia from the findings of serum amylase by $11 \mathrm{~S}$ IgA globulin. New Eng J Med, 278: 474, 1968. 4) Hedger, RW and Haridson, GM: Trancient macroamylasemia during an exacerbation of acute intermittent porphyria. Gastroenterology, 60: 903, 1971. -5) Levitt, MD, et al: Two forms of macroamylasemia. The La ncet, 1: 957, 1968. -6) 石井兼 次: Macroamylasemia の一例, 内科, 27: 897, 1972. 一7) 池田健次郎, 他: Macroamylasemiat 呈した肝硬变症の 1 例。日内会誌, $61: 81,1971$. 
一8) 三輪晃一,他: Macroamylasemiaの一例, 日本 膵藏病研究会ブロシーディンダス，2:87，1972, 一9)小悦子, 他：9 S macroamylaseの性質につ いて，躁床化学，1：192，1972，一10) 本田英輔, 他：気道及び尿路感染を伴ったmacroamylasemia の 1 例，日内会誌，61:12，1534，1972，一11) 原田 㓆久子，北村元仕：原発性肺癌症例で遭避しだフ ラーゼ、フインェンザイム，医学と生物学，82: 155，1971. - -12) 北村元仕：Amylase isoenzyme, 内科, $29: 5,834,1972$. -13) Sweeney, DF and Finkel, M: Hyperamylasemia of renal origin in the absence of azotemia. Gastroenterology, 45: 756, 1963. -14) Hansen, HR: Macroamylasemia due to binding by protein, Amer J Med, 52：712，1972. -15) 小網悦子，尾形稳：IgA結 合amylase ( $9 \mathrm{~S}$ macroamylase), 臨床化学, 20 補 冊：65，1974，一16) 原田紀久子，他：マクロフ ミラセミフにおけるフミラーゼ電気洙動像の異常， 医学のあゆ，90(10):789，1974。－17) 原田紀 久子，北村元仕：Macroamylasemia. 診断と治療 : 60(11): 82, 1972 . 